Acta Universitatis Wratislaviensis No 3705

PRAWO CCCXX

Wrocław 2016

DOI: $10.19195 / 0524-4544.320 .7$

EWA PIERZCHAŁA

Uniwersytet Opolski

e-mail: epierzchala@uni.opole.pl

\title{
Umowa o ponoszenie opłat za pobyt w domu pomocy społecznej w orzecznictwie sądów administracyjnych
}

\section{Uwagi wprowadzające}

Umowa jako forma prawna działań organów administracji publicznej należy do zagadnień, na tle których dochodzi do sporów natury doktrynalnej i praktycznej. Zauważalna jest $\mathrm{w}$ prawdzie trwała tendencja do rozszerzania zastosowania tej formy działań w obszarze administracji, ale niewątpliwie wraz zainteresowaniem rośnie również katalog wątpliwości co do właściwego modelu umowy, jej obszarów zastosowania, jak również sposobów egzekwowania. Należałoby zauważyć, że umowa współcześnie stanowi alternatywę dla załatwiania spraw, dla których tradycyjnie przewidziany był władczy sposób działania. Forma działań, która jest przedmiotem niniejszego opracowania, należy niewątpliwie do aktów stosowania prawa, w których wymagane jest zgodne oświadczenie woli dwóch stron. Zaznaczyć jednocześnie należy, że nie jest to akt cywilnoprawny. Zważywszy na fakt, że $\mathrm{w}$ administracji publicznej umowa nie jest typową formą załatwiania spraw, wyjaśnienia wymaga jej istota w zakresie stosowania prawa administracyjnego. Prawo cywilne, jako gałąź prawna zawierająca normy regulujące kwestie umów, jest $\mathrm{w}$ ostatnim czasie nauką silnie ingerującą $\mathrm{w}$ inne gałęzie prawa, w tym również w prawo administracyjne. I nie chodzi tu bynajmniej o to, aby zainicjować dyskusję nad nowymi kierunkami rozwoju prawa, ale o to, aby znaleźć obszary działań administracji, w których umowa jest lub może być stosowana w celu poprawy skuteczności jej działania. Jak podkreśla się w doktrynie, „umowa jako forma działania administracji znajduje szersze zastosowanie tam, gdzie pewne dziedziny życia gospodarczego zostały znacjonalizowane, gdzie państwo wystę- 
puje jako właściciel określonych dóbr i dlatego może korzystać z form przewidzianych przez prawo cywilne" ${ }^{1}$. Dotychczasowy dorobek doktryny ${ }^{2} \mathrm{w}$ pewnym niezbędnym stopniu porządkuje kwestie związane ze stosowaniem form konsensualnych w administracji, jednakże brak regulacji prawnych w tym obszarze pozostawia nadal przeświadczenie niepewności bytu tych form. Jednolity i trwały model umowy cywilnoprawnej nie jest możliwy do przeniesienia w sposób bezkrytyczny i bezpośredni na grunt prawa administracyjnego.

Warto powtórzyć za J. Bociem, że ,ideą umowy administracyjnoprawnej jest wyposażenie obywatela lub innego, zewnętrznego wobec administracji publicznej podmiotu w możliwość optymalnego zjednoczenia interesu publicznego z jego interesem indywidualnym, a jeśli nie zjednoczenia, to jednoczesnego ulepszenia ochrony obydwu tych interesów"3.

Ciekawe rozwiązanie wykorzystania umowy w prawie administracyjnym przewiduje ustawodawstwo niemieckie. W nauce prawa niemieckiego wyróżnia się dwa rodzaje umów administracyjnych: subordynacyjnoprawną i koordynacyjnoprawną ${ }^{4}$. Pierwsza kategoria umów może zastępować akt administracyjny, zawierać zobowiązanie do wydania takiego aktu lub nie pozostawać w żadnym związku z aktem administracyjnym. Jedną ze stron takiej umowy jest przedstawiciel administracji publicznej, drugą zaś obywatel lub inny, niepozostający w organizacyjnym związku z administracją podmiot. Natomiast umowa koordynacyjnoprawna zawierana jest przez podmioty o równoważnych pozycjach w warunkach, w których nie można wydać aktu administracyjnego ${ }^{5}$.

Niewątpliwie w doktrynie zauważa się „ewidentną potrzebę wprowadzenia do polskiego systemu prawa administracyjnego instytucji umowy administracyjnej, odpowiadającej swą konstrukcją niemieckiej publicznoprawnej umowie subordynacyjnej"6. Koncepcja umowy, jak podkreśla się w literaturze prawa administracyjnego, ma ogromne znaczenie. „Zarówno strony postępowań, jak i organy administracji publicznej, na pewnym etapie postępowań, dostrzegają po-

1 E. Ochendowski, Prawo administracyjne. Część ogólna, Torun 2013, s. 225.

2 Zob. J. Lemańska, Umowa administracyjna a umowa cywilnoprawna, [w:] Instytucje wspótczesnego prawa administracyjnego. Księga Jubileuszowa Profesora zw. dra hab. Józefa Filipka, red. I. Skrzydło-Niżnik et al., Kraków 2001, s. 421 n.; P. Przybysz, Umowa jako forma działań administracji w świetle pogladów Profesora Jerzego Starościaka, [w:] Umowy w administracji publicznej, red. J. Boć, L. Dziewięcka-Bokun, Wrocław 2008, s. 123 n.; J. Starościak, Prawne formy i metody działań administracji, [w:] System prawa administracyjnego, t. 3, red. T. Rabska, J. Łętowski, Wrocław 1978, s. 39 n.; J. Wyporska-Frankiewicz, Publicznoprawne formy działań administracji o charakterze dwustronnym, Warszawa 2010; P. Stec, Umowy w administracji. Studium cywilnoprawne, Warszawa 2013.

3 J. Boć, O umowie administracyjnoprawnej, [w:] J. Boć, L. Dziewięcka-Bokun, op cit, s. 30.

4 Zob. I. Richter, G.F. Schuppert, Casebook. Verwaltungsrecht, München 1995, cyt. za: Z. Cieślik, Umowa administracyjna, Kraków 2008, s. 42.

5 Ibidem, s. 42.

6 M. Rypina, M. Wierzbowski, Umowa z organem w postępowaniu administracyjnym, „Państwo i Prawo" 2010, z. 4, s. 15. 
trzebę konsensu również w sferze stosunków publicznoprawnych. Nadanie ram prawnych wzajemnym ustaleniom podmiotu administrującego i administrowanego, a więc usankcjonowanie wzajemnych ustępstw i zobowiązań o charakterze publicznoprawnym, mogłoby w prosty sposób zakończyć niejedną długotrwałą i zawiłą sprawę" ".

Celem niniejszego opracowania jest analiza i ocena charakteru prawnego umowy o ponoszeniu opłat za pobyt $\mathrm{w}$ domu pomocy, ze szczególnym uwzględnieniem warunków wydania decyzji w sytuacji, gdy do jej zawarcia by nie doszło. Podstawowym tłem do rozważań będzie liczne orzecznictwo sądów administracyjnych. Podjęta zostanie próba wskazania głównych problemów związanych ze stosowaniem tej cywilnoprawnej instytucji w prawie administracyjnym w zakresie pomocy społecznej.

Umowa o partycypacji w kosztach utrzymania osoby w DPS jest ważnym problemem współczesnego społeczeństwa, a tym samym administracji publicznej. Finansowanie opieki osób bliskich, którzy nie mogą z różnych względów liczyć na pomoc swoich zstępnych, chociażby na skutek silnej emigracji zarobkowej, jest dzisiaj problemem wszystkich rozwijających się społeczeństw. System pomocy społecznej oraz konstrukcja prawna alimentacji prowadzi do ukształtowania się procesowej drogi kształtowania wykonania obowiązku partycypacji w kosztach utrzymania osób potrzebujących pomocy. Rolą ustawodawcy i aparatu administracyjnego jest zaproponowanie takich rozwiązań, które zapewnią sprawną realizację ustawowego obowiązku. Obecny stan prawny jest z kolei źródłem wielu wątpliwości interpretacyjnych, co odzwierciedla bogate i niejednolite orzecznictwo. Stąd też wymagana jest pogłębiona dyskusja i analiza przepisów prowadząca do konstruktywnych zmian w tym zakresie.

\section{Stosunki prawne w zakresie pomocy społecznej}

System pomocy społecznej w Polsce korzysta z wielu dyscyplin naukowych. Zaliczyć można do nich chociażby prawo, ekonomię, socjologię i pedagogikę. W obszarze nauk prawnych system ten wyróżnia stosunki prawnoadministracyjne oraz stosunki prawnocywilne. Podstawowym celem nawiązywania stosunków prawnych w pomocy społecznej jest realizacja zasady udzielania wsparcia osobom potrzebującym. Zdecydowana większość relacji prawnych ma charakter administracyjnoprawny chociażby $\mathrm{z}$ uwagi na fakt zakwalifikowania norm prawa pomocy społecznej do gałęzi prawa administracyjnego. Taki charakter będą miały przede wszystkim decyzje administracyjne przyznające prawo do korzystania z pomocy. Stosunki te charakteryzują się przede wszystkim niekontradyktoryj-

7 Ibidem, s. 16. 
nością, co oznacza, że treść decyzji kształtowana jest przez organ administracji publicznej w granicach przyznanych mu kompetencji. Natomiast spory powstałe w związku z realizacją lub brakiem realizacji postanowień decyzji rozstrzyga organ nadrzędny, a w dalszej kolejności sąd administracyjny. „Mimo że z charakterystyki typowego stosunku administracyjnoprawnego wynika nierównorzędność i nadrzędność, to w rzeczywistości cechy te są znacznie złagodzone, a niekiedy w ogóle nie występują. Wiele stosunków regulowanych prawem administracyjnym zakłada współdziałanie stron i ich formalną równość. Przykładem takich stosunków może być: współpraca organów administracji z organizacjami pozarządowymi zajmującymi się pomocą społeczną, zawieranie porozumień między organami administracji publicznej w sprawie przekazania zadań z zakresu pomocy społecznej"8.

W relacjach pomiędzy podmiotami w obszarze pomocy społecznej wyróżnia się również stosunki cywilnoprawne. Zarówno o nawiązaniu takiego stosunku prawnego, jak i o jego treści oraz wzajemnych prawach i obowiązkach decydują strony. Natomiast wszelkie spory wynikłe na tle konfliktu pomiędzy stronami rozstrzygają sądy powszechne. Przykładem typowego stosunku cywilnoprawnego będzie umowa o realizację pieczy zastępczej. Jak twierdzi I. Sierpowska, „wykorzystanie umów cywilnoprawnych w pomocy społecznej bywa często bardziej racjonalne i skuteczne niż posługiwanie się władztwem. Nie koliduje to w żaden sposób z przynależnością pomocy społecznej do prawa administracyjnego, zwłaszcza w obliczu rozwijających się nie władczych form działań administracji publicznej"9.

W prawie pomocy społecznej istnieje cały szereg umów, których charakter prawny nie jest do końca określony. Zadania prawidłowej klasyfikacji tych czynności nie ułatwia fakt braku wyodrębnienia normatywnego instytucji umowy administracyjnoprawnej.

\section{Problematyka umowy na rzecz osób bliskich w prawie pomocy społecznej}

Umowy jako prawne formy działań nigdy nie stanowiły w pomocy społecznej głównego filaru katalogu form działań administracji. Jednak w świetle obowiązującego prawa trudno odmówić im doniosłego charakteru. Praktyka stosowania prawa, zwłaszcza w konkretnych regulacjach prawnych, wprowadza wprost obowiązek organów do zawierania umów bez określania ich warunków formal-

8 I. Sierpowska, Prawo pomocy społecznej, Kraków 2006, s. 42.

9 Ibidem. 
nych oraz trybu. Ustawa o pomocy społecznej ${ }^{10}$ wyróżnia wiele umów zawieranych $w$ celu realizacji misji, jaką niesie ze sobą pomoc społeczna. Jedną z nich jest umowa zawierana z osobami bliskimi osoby potrzebującej w celu udzielenia pomocy. Pierwszy rodzaj ustawodawca określił mianem kontraktu socjalnego ${ }^{11}$.

W literaturze przedmiotu ten rodzaj umowy nie został przyjęty zbyt optymistycznie. Problem ten odnosi się chociażby do wielu kwestii nieuregulowanych w art. 103 ust. 1 i 2 u.p.s., a których stosowanie jest wymagane $\mathrm{z}$ uwagi na realizację obowiązku udzielenia pomocy. Przepis art. 103 rozróżnia umowę fakultatywną i obligatoryjną. Pierwsza dotyczy dobrowolnego partycypowania osób bliskich w świadczeniach dla beneficjenta pomocy (art. 103 ust. 1 u.p.s.), druga zaś umowy obligatoryjnej zawieranej w przypadku konieczności ustalenia proporcji partycypowania w kosztach umieszczenia podopiecznego $\mathrm{w}$ domu pomocy społecznej (art. 103 ust. 2 u.p.s.). Zwłaszcza drugi rodzaj umowy nasuwa szereg wątpliwości. Brak jest bowiem typowych dla umowy norm. Ustawodawca nie zawarł w przepisach tzw. essentialia negotii umowy, co prowadzi w praktyce do różnych błędów w sporządzaniu tego aktu. W doktrynie przyjmuje się, że „umowa powinna być zawarta na piśmie i określać w szczególności formę i rozmiar świadczonej pomocy oraz okres, na jaki została zawarta. Stronami umowy są: małżonek, określeni zstępni lub wstępni oraz kierownik ośrodka pomocy społecznej lub kierownik powiatowego centrum pomocy rodzinie"12. Wątpliwości dotyczą również sytuacji, w której w przypadku obowiązku zawarcia umowy strony nie dojdą do porozumienia albo w ogóle nie wyrażą woli jej zawarcia. Z treści przepisu art. 103 ust. 2 u.p.s. nie wynika, że umowa może być zastąpiona inną formą. Regulacja art. 103 u.p.s. wydaje się być konsekwencją instytucji alimentacji. W kwestii wskazanej powyżej w odniesieniu do sytuacji, gdzie strony umowy nie mają woli złożenia zgodnych oświadczeń, ustawodawca pozostawił pewną lukę prawną, bowiem regulacja przepisów ustawy o pomocy społecznej dotyczy dopiero okoliczności, gdy osoby bliskie nie wywiązują się z obowiązku opłaty za pobyt $\mathrm{w}$ domu pomocy społecznej beneficjenta. Przepis art. 61 ust. 3 wskazuje ponadto, że w sposób uzupełniający opłatę tę wnosi gmina. Jednakże trudno jest zaaprobować sytuację, w której osoby bliskie uchylają się od zawarcia umo-

10 Ustawa z dnia 12 marca 2004 r. o pomocy społecznej (tekst jedn. Dz.U. z 2015 r., poz. 163), zwana dalej u.p.s.

${ }^{11}$ Zob. na temat kontraktu socjalnego m.in. E. Prandota-Prandecka, Kontrakt socjalny jako narzędzie rozwiazywania trudnej sytuacji życiowej beneficjenta pomocy społecznej — zagadnienia wybrane, [w:] Umowy w administracji..., s. 371 n.; A. Kłos, Kontrakt socjalny w teorii $i$ w praktyce, Warszawa 2011; J. Wyporska-Frankiewicz, R. Cybulska, Kontrakt socjalny jako doskonate narzędzie stużące wspótdziałaniu $w$ wykonywaniu zadań z zakresu pomocy społecznej ciążących na administracji publicznej, [w:] Formy współdziałania jednostek samorządu terytorialnego, red. B. Dolnicki, Warszawa 2013, s. 221 n.; L. Zacharko, R. Cybulska, E. Prandota-Prandecka, Kontrakt socjalny. Pracownik socjalny, Wrocław 2011.

12 I. Sierpowska, Ustawa o pomocy społecznej. Komentarz, Warszawa 2009, s. 404. 
wy, przenosząc całkowity koszt utrzymania na gminę. Ustawodawca nie odniósł się do tych kwestii wprost. W doktrynie znany jest pogląd, że odmowa zawarcia umowy „nie może przesądzać o nieprzyznaniu świadczenia, ale może skutkować wytoczeniem powództwa o roszczenie alimentacyjne na podstawie art. 110 ust. 5 i 112 ust. 3 u.p.s." ${ }^{\prime 13}$ Można zatem postawić pytanie, czy istnieje możliwość, a tym samym podstawa prawna do wydania decyzji zobowiązującej osoby bliskie wymienione w art. 103 ust. 2 u.p.s. do ponoszenia kosztów pobytu podopiecznego. $\mathrm{Na}$ tle przedstawionych problemów wyłania się konieczność sięgnięcia do wykładni przepisów proponowanej przez sądy administracyjne.

\section{Kierunki poglądów dotyczących umowy na rzecz osób bliskich w orzecznictwie}

Orzecznictwo jako nienazwane źródło prawa ${ }^{14}$ pełni ogromną rolę w kształtowaniu praktyki urzędniczej. Ta bowiem bezpośrednio wpływa na kształtowanie sytuacji prawnej i faktycznej obywateli. Na tle dotychczasowego dorobku sądów administracyjnych można wyróżnić dwa zasadnicze problemy w zakresie analizowanej umowy. Pierwszy dotyczy źródła i formy kształtowania się obowiązku partycypacji w kosztach utrzymania swoich bliskich w instytucjach pomocy społecznej. Osobną problematykę stanowi sytuacja, w której nie dochodzi do dobrowolnego zawarcia umowy o partycypację w kosztach utrzymania podopiecznego w domach pomocy społecznej.

Pierwszy prezentowany problem dotyczący art. 103 ust. 2 u.p.s. sprowadza się do ustalenia, czy na podstawie tego przepisu można wywieść, że obowiązek wnoszenia opłat za pobyt $\mathrm{w}$ domu pomocy społecznej wynika $\mathrm{z}$ ustawy, a nie z umowy, a umowa służy jedynie określeniu wysokości opłaty. Czy też można przyjąć, że obowiązek ten wynika z decyzji o ustaleniu opłaty za pobyt w domu pomocy społecznej przewidzianej w art. 59 ust. 1 u.p.s, a umowa, tak jak w poprzednim przypadku, go konkretyzuje. Według pierwszego nurtu, prezentowanego m.in. przez NSA, ,zawarcie umowy, o której mowa w art. 103 ust. 2 ustawy, służy jedynie określeniu wysokości opłaty, natomiast sam obowiązek jej uiszczenia wynika z mocy ustawy, a nie z umowy" ${ }^{\prime 15}$. Oznacza to, że Sąd przyjął, iż umowa nie jest źródłem obowiązku, nie jest nim również inna decyzja, a jedynie konkretyzacja tego obowiązku następuje w drodze innego niż ustawa aktu praw-

13 Ibidem, s. 403.

$14 \mathrm{Na}$ temat otwartego systemu źródeł prawa zob. F. Longchamps de Bérier, $W$ sprawie pojęcia administracji państwowej i pojęcia prawa administracyjnego, Wrocław 1957, (,Zeszyty Naukowe Uniwersytetu Wrocławskiego" nr 10) oraz Prawo administracyjne, red. J. Boć, Wrocław 2010, s. 116

15 Wyrok NSA z dnia 9 stycznia 2015, I OSK 1615/13, LEX 1624282. 
nego. $Z$ tego faktu można również wywnioskować, że osoby, które bez uszczerbku dla utrzymania siebie lub swoich bliskich nie mogą wykonać obowiązku ustawowego, mają prawo ubiegać się o zwolnienie z tego obowiązku na podstawie art. 64 u.p.s., co potwierdza również wyrok WSA we Wrocławiu ${ }^{16}$. Podobny pogląd prezentuje WSA w Szczecinie. Zdaniem Sądu „Obowiązek ten wynika z mocy ustawy, ale w celu jego realizacji konieczne jest skonkretyzowanie tego obowiązku poprzez zawarcie stosownej umowy, o której mowa w art. 103 ust. 2 u.p.s., bądź też poprzez wydanie władczego aktu (decyzji wydanej na podstawie art. 104 ust. 3) przez organ gminy, na obszarze którego mieszka osoba skierowana do domu pomocy społecznej (zgodnie z art. 59 ust. 1 oraz art. 61 ust. 3), jeżeli wystąpi sytuacja, o której mowa w art. 61 ust. 3 u.p.s. ${ }^{17 "}$. Stanowisko takie prezentuje również WSA w Poznaniu. W swoim wyroku Sąd stwierdził, że ,pobyt w domu pomocy społecznej jest odpłatny, a obowiązek wnoszenia opłaty przez konkretną osobę, czy osoby spośród kręgu podmiotów zobowiązanych na mocy art. 61 ust. 1 i ust. 2 pkt 1 i 2 u.p.s. kreuje decyzja administracyjna o ustaleniu opłaty za pobyt $\mathrm{w}$ domu pomocy społecznej przewidziana w art. 59 ust. 1 u.p.s. Umowa, o której mowa w art. 103 ust. 2 tej ustawy, nie jest wyłącznym źródłem obowiązku ponoszenia opłat przez te osoby za pobyt w domu pomocy społecznej. Z samego brzmienia art. 103 ust. 2 wynika, że celem takiej umowy nie jest nawiązanie cywilnoprawnego stosunku zobowiązującego do ponoszenia opłat za pobyt w domu pomocy społecznej, ale ustalenie wysokości opłaty wnoszonej przez zobowiązane osoby, a więc opłaty, której obowiązek ponoszenia został już ustawowo ustalony" 18 .

$\mathrm{W}$ orzecznictwie można również znaleźć zgoła odmienne stanowiska. Inną od zaprezentowanej powyżej koncepcję prezentuje m.in. WSA w Lodzi. Zgodnie z tezą wyroku tego Sądu „Dopóki umowa nie zostanie zawarta, dopóty po stronie małżonka, zstępnego lub wstępnego nie istnieje skonkretyzowany i prawnie skuteczny obowiązek ponoszenia opłaty za pobyt w domu pomocy społecznej"19. W podobnym kontekście wypowiada się również WSA w Gorzowie Wielkopolskim. Zdaniem Sądu „Obowiązek wnoszenia opłat za pobyt w domu pomocy społecznej przez konkretną osobę spośród kręgu podmiotów zobowiązanych na mocy art. 61 ust. 1 i ust. 2 pkt 1 i 2 u.p.s. kreuje nie umowa, o jakiej mowa w art. 103 ust. 2, ale decyzja administracyjna o ustaleniu opłaty za pobyt $\mathrm{w}$ domu pomocy społecznej przewidziana w art. 59 ust. 1 u.p.s" ${ }^{20}$. Nie do końca jasne jest natomiast stanowisko WSA w Gliwicach, zgodnie z którym „Obowiązek partycypowania w kosztach utrzymania osoby skierowanej do domu pomocy społecznej osób wymienionych w art. 61 ust. 2 pkt 2 u.p.s. powinien zatem zostać określony już w decyzji o skiero-

16 Zob. Wyrok WSA we Wrocławiu z dnia 21 maja 2009 r., IV SA/Wr 562/08, LEX 580398.

17 Wyrok WSA w Szczecinie z dnia 19 marca 2015r., II SA/Sz 855/14, LEX 1760749.

18 Wyrok WSA w Poznaniu z dnia 14 maja 2014 r., II S/Po 89/14, LEX 1474200.

19 Wyrok WSA w Łodzi z dnia 26 marca 2016 r., II SA/Łd 50/14, LEX 1522706.

20 Wyrok WSA w Gorzowie Wielkopolskim z dnia 7 września 2015 r., II SA/Go 202/15, LEX 1760172 
waniu do domu pomocy społecznej i o ustaleniu opłaty za pobyt" ${ }^{21}$. Koncepcja ta zakłada bowiem, że źródłem obowiązku partycypacji w kosztach utrzymania osoby skierowanej do domu pomocy społecznej jest już sama decyzja o skierowaniu do tej jednostki, a nie ustawa lub decyzja o ustaleniu opłaty.

Z powyższej analizy orzeczeń wynika, że praktyka orzecznicza w przeważającej części wykształciła pogląd o możliwym istnieniu trzech źródeł zobowiązania: ustawy - w zakresie ogólnego obowiązku ponoszenia opłaty, decyzji o ustaleniu opłaty - w zakresie ustalenia ponoszenia opłaty przez konkretne osoby i umowy — jako źródła ustalenia wysokości opłaty. Oznacza to, że najlepszym rozwiązaniem jest przyjęcie założenia, że obowiązek partycypacji w kosztach za pobyt podopiecznego $\mathrm{w}$ domu pomocy społecznej wynika $\mathrm{z}$ ustawy, a umowa jedynie indywidualizuje ten obowiązek.

Kolejnym problemem, wyraźnie widocznym w praktyce orzeczniczej, jest sytuacja, w której nie dochodzi do dobrowolnego zawarcia umowy, o której mowa w art. 103 ust. 2 u.p.s. Według jednego poglądu można umowę zastąpić decyzją administracyjną. Zgodnie z innym — należy na drodze postępowania cywilnego zastąpić oświadczenie woli stron wyrokiem sądu powszechnego. Dopuszczalność pierwszej koncepcji zauważyć można m.in. w orzeczeniu WSA w Rzeszowie. Zgodnie z treścią wyroku „Niezawarcie umowy nie jest przesłanką niezbędną do wydania decyzji ustalającej odpłatność za pobyt w domu pomocy społecznej. Umowa, o której mowa nie musi być zawarta z małżonkiem, wstępnym czy zstępnym aby organ ustalił opłatę za pobyt $\mathrm{w}$ formie decyzji administracyjnej na podstawie art. 59 ust. 1 u.p.s." ${ }^{2}$ Podobnie stwierdził WSA w Bydgoszczy: „Przy negatywnej postawie osób zobowiązanych do wnoszenia opłat za pobyt $\mathrm{w}$ domu pomocy społecznej ich członka rodziny, przejawiającej się udokumentowaną odmową podpisania umowy, o której mowa w art. 103 ust. 2 u.p.s., organ powinien wydać decyzję na podstawie art. 104 ust. 3 w związku z art. 61 ust. 3 u.p.s., w której zostałaby określona wysokość opłaty za pobyt mieszkańca w domu pomocy społecznej wniesionej zastępczo przez gminę oraz osoba zobowiązana do zwrotu należności" "23. Odmowa zawarcia umowy z osobami zobowiązanymi do partycypacji w kosztach jest podstawą do wszczęcia czynności egzekucyjnych. Jak zauważa WSA we Wrocławiu: „Właściwą drogą wyegzekwowania takich należności przez gminę jest wydanie decyzji na podstawie art. 104 ust. $3 \mathrm{w}$ związku $\mathrm{z}$ art. 61 ust. 3 u.p.s." ${ }^{24}$ Pogląd taki wyraził również WSA w Warszawie, twierdząc, że „Skoro więc obowiązek członków rodziny osoby umieszczonej w domu pomocy społecznej, polegający na wnoszeniu związanych z tym opłat wynika wprost z art. 61 ust. 1 pkt 2 u.p.s., to w sytuacji uchylania się od tego obowiązku przez osoby zobowiązane, gmina, która zastępczo poniosła wydatki, może egzekwować ich

21 Wyrok WSA w Gliwicach z dnia 5 czerwca 2015 r., IV SA/G1 877/13, LEX 1508507.

22 Wyrok WSA w Rzeszowie z dnia 15 stycznia 2014 r., II SA/Rz, 1217/13, LEX 1424410.

23 Wyrok WSA w Bydgoszczy z dnia 9 października 2012 r., II SA/Bd 591/12, LEX 1248572.

24 Wyrok WSA we Wrocławiu z dnia 2 kwietnia 2012 r., II SA/Wr, 701/11, LEX 1275208. 
zwrot na drodze administracyjnej. Właściwą drogą wyegzekwowania takich należności przez gminę jest wydanie decyzji na podstawie art. 104 ust. 3, w związku z art. 61 ust. 3 u.p.s." 25 Odmienne stanowisko prezentuje natomiast WSA w Łodzi. Zgodnie z wyrokiem tego Sądu „Istnienie umowy jest niezbędnym elementem do tego, aby po stronie gminy powstało uprawnienie do domagania się zwrotu poniesionych przez gminę wydatków w trybie przepisu art. 61 ust. 3 u.p.s. Bez zawarcia umowy nie istnieje możliwość postawienia komukolwiek z owych osób zarzutu niewywiązania się z obowiązku ponoszenia opłat $\mathrm{z}$ tytułu pobytu $\mathrm{w}$ dps członka rodziny"26. Przy założeniu, że obowiązek ponoszenia kosztów utrzymania podopiecznych w domu pomocy społecznej wynika z ustawy, prezentowany pogląd nie jest do przyjęcia.

W zdecydowanej mniejszości pozostaje więc koncepcja zastąpienia oświadczeń woli stron umowy o partycypację w kosztach pobytu w domu pomocy społecznej wyrokiem sądu. Taką opcję prezentuje m.in. WSA w Warszawie. Zgodnie $\mathrm{z}$ tezą tego wyroku „W sytuacji, gdy małżonek lub krewny mieszkańca domu pomocy społecznej odmawia podpisania umowy, o której mowa w art. 103 ust. 2 u.p.s., to organ pomocy społecznej winien wystąpić do sądu powszechnego z roszczeniem opartym na przepisie art. 64 k.c. Niedopuszczalne jest natomiast wydanie decyzji administracyjnej na podstawie art. 104 ust. $3 \mathrm{w}$ związku z art. 61 ust. 3 u.p.s., w odniesieniu do osób zobowiązanych na podstawie umowy do wnoszenia opłat za pobyt $\mathrm{w}$ domu pomocy ich członka rodziny" ${ }^{27}$. Z tezą taką nie można się jednak zgodzić, ponieważ u jej podstawy leży koncepcja cywilnoprawnego ukształtowania stosunku prawnego pomiędzy kierownikiem ośrodka pomocy społecznej a osobami zobowiązanymi do partycypacji. Jednak jeśli przyjmiemy poprzednie założenie, że obowiązek partycypacji wynika z ustawy i ma on charakter administracyjny, to oczywista staje się teza, że umowa, która zostaje zawarta w celu konkretyzacji tego obowiązku, będzie miała charakter administracyjny, co wyklucza działanie sądów powszechnych.

Poddając analizie aktualne orzecznictwo w tym zakresie, można dojść do wniosku, że jedyną słuszną drogą jest przyjęcie założenia, że w konsekwencji braku zawarcia umowy można wystąpić na drogę postępowania administracyjnego i ustalić wysokość opłaty i jednocześnie zwrotu tej opłaty w drodze decyzji administracyjnej. Należy podkreślić, że możliwość zastąpienia umowy, o której mowa w art. 103 ust. 2 u.p.s. decyzją administracyjną z wszelkimi tego konsekwencjami (np. egzekucyjnymi) dopuszcza nawet Sąd Najwyższy. Jedno z orzeczeń stanowi, że „Ustawodawca przewidział mechanizm efektywnej realizacji tego obowiązku (partycypacji w kosztach umieszczenia podopiecznego w DPS - informacja dodana przez autora), stosownie bowiem do art. 104 ust. 3 u.p.s., wysokość należno-

25 Wyrok WSA w Warszawie z dnia 15 stycznia 2010 r., II SA/Wa, 1171/09, LEX 594941.

26 Wyrok WSA w Łodzi z dnia 7 marca 2013 r., II SA/Łd 1172/12, LEX 1303649.

27 Wyrok WSA w Warszawie z dnia 9 grudnia 2009 r. , II SA/Wa 537/09, LEX 583656. 
ści podlegającej zwrotowi oraz termin zwrotu tej należności ustala się w drodze decyzji administracyjnej, poprzedzonej oceną sytuacji osobistej, rodzinnej, dochodowej i majątkowej zobowiązanego (art. 107 ust. 1 u.p.s.). Według zaś art. 104 ust. 1 u.p.s., należności z tytułu wydatków na świadczenia z pomocy społecznej z tytułu opłat określonych przepisami niniejszej ustawy oraz z tytułu nienależnie pobranych świadczeń podlegają ściągnięciu w trybie przepisów o postępowaniu egzekucyjnym w administracji" 28 .

\section{Uwagi końcowe}

Na tle powyższych rozważań nasuwa się podstawowy wniosek o niewątpliwej potrzebie ukształtowania nowej koncepcji umowy odpowiadającej warunkom administracyjnym i wprowadzenia odpowiednich regulacji prawnych. Nie sposób nie zauważyć, że próby uregulowania normatywnego podejmowano już niejednokrotnie poprzez projekt ustawy Przepisy ogólne prawa administracyjnego ${ }^{29}$. Niestety dotychczas żaden z przedstawianych projektów nie stał się obowiązującym prawem. Warto jednak przypomnieć, że zarys konstrukcji prawnej umowy administracyjnej został zaproponowany jako przepis art. 41 Projektu, zgodnie z którym „Organ administracji publicznej, właściwy do załatwienia sprawy, o której mowa $\mathrm{w}$ art. 1, w drodze decyzji administracyjnej albo poprzez podjęcie innego aktu lub czynności władczej, uprawniony jest do zawarcia umowy z osobami, których interesów prawnych lub obowiązków sprawa dotyczy, o ile nie stoją temu na przeszkodzie przepisy szczególne (umowa administracyjna)" ${ }^{30}$. Zaproponowana treść przepisu odzwierciedlała dotychczasowy dorobek doktryny i stanowiła o kierun$\mathrm{ku}, \mathrm{w}$ jakim ocena prawna czynności konsensualnych w administracji powinna zmierzać.

W doktrynie prawa administracyjnego prezentowano wiele poglądów co do konstrukcji prawnej umowy publicznoprawnej. Podstawowe cechy umowy przedstawił m.in. M. Kania, zaliczając do nich:

— posiadanie przez jedną ze stron umowy statusu publicznoprawnego,

- treść umowy związana jest ze sferą zadań publicznych obciążających administrację publiczną,

- wywołuje ona skutki bezpośrednio w sferze prawa administracyjnego,

- umowa związana jest bezpośrednio z realizacją interesu prawnego,

— występuje w treści umowy wyraźne ograniczenie zasady swobody umów,

28 Uchwała SN z dnia 29 października 2009 r., III CZP 77/09, niepublikowany.

$29 \mathrm{http} / / /$ orka.sejm.gov.pl/Druki6ka.nsf/0/8F21C6C714261B99C1257849003B79D6/\$file/3942. pdf (dostęp: 19.12.2015).

30 Art. 41 Projektu ustawy Przepisy ogólne prawa administracyjnego, druk sejmowy nr 3942. 
— właściwość sądów administracyjnych do rozpatrywania sporów związanych z realizacją postanowień umowy,

— podmiot publiczny posiada znacznie silniejszą, uprzywilejowaną pozycję wobec drugiej strony kontraktu ${ }^{31}$.

Nie sposób nie wspomnieć, że umowa jako prawna forma załatwiania spraw znalazła również swoje odzwierciedlenie w propozycji zmian do Kodeksu postępowania administracyjnego ${ }^{32}$.

Warto zauważyć, że specyfika zadania publicznego, jakim jest pomoc społeczna, pozostawia szerokie spektrum możliwości w zakresie wyboru form działań. W ostatnich kilku latach wprowadzono do regulacji prawnych z zakresu pomocy społecznej instytucje o charakterze konsensualnym, które z powodzeniem przyjęły się w praktyce (np. kontrakt socjalny, umowa pieczy zastępczej). Umowa daje bowiem możliwość współdecydowania, a co za tym idzie, tworzy dla stron taki sam zakres odpowiedzialności za wykonanie przyjętych na siebie zobowiązań. Prawidłowa i zgodna z prawem umowa lepiej realizuje zasadę celowości wynikającą z ustawy o pomocy społecznej aniżeli decyzja administracyjna.

Podsumowując dotychczasowe rozważania, można wskazać, że oto mamy do czynienia z tendencją do tworzenia tzw. administracji kontraktowej. Jest to tendencja stała, długotrwała, odzwierciedlająca się w rozproszonej regulacji prawnej. Być może wzorem ustawodawstwa francuskiego lub niemieckiego kolejnym etapem będzie stworzenie normatywnego modelu umowy odpowiadającej jej publicznemu charakterowi.

Konsekwencją przyjętego wyżej założenia jest również treść przepisu art. 103 u.p.s. wprowadzającego do systemu pomocy społecznej dwustronną formę działania w obszarze partycypacji osób bliskich w kosztach utrzymania osoby skierowanej do domów pomocy społecznej. Wątpliwości i różnorodna praktyka orzecznicza nie sprzyjają jednak efektywnemu wykonywaniu tej normy. $\mathrm{Na}$ uwagę zasługuje dość liczne orzecznictwo w tym zakresie, co świadczy o dużym zainteresowaniu praktycznym tą instytucją. Zważywszy jednak na rozbieżności w tezach wyroków sądów administracyjnych, niezwykle trudno jest ukształtować jednolitą interpretację wątpliwej treści normy art. 103 ust. 2 u.p.s. Można jednak podjąć próbę ustalenia rozwiązania postawionych na wstępie problemów i stwierdzić, że obowiązek partycypacji w kosztach za pobyt podopiecznego w domu pomocy społecznej wynika z ustawy, a umowa jedynie indywidualizuje ten obowiązek i jeśli podmiot uchyla się od zawarcia umowy, to organ konkretyzację obowiązków powinien określić w decyzji. Podstawą prawną decyzji będzie wówczas art. 104 ust. 3 , art. 59 ust. $1 \mathrm{w}$ zw. $\mathrm{z}$ art. 60 ust. 1 , art. 61 ust. 1 pkt 2 i ust. 2

31 Zob. M. Kania, Partnerstwo publiczno-prywatne. Teoria i praktyka, Warszawa 2013, s. $176-177$.

32 http://www.nsa.gov.pl/wydarzenia-wizyty-konferencje/konferencja-dotyczaca-reformy-prawao-postepowaniu-administracyjnym-raport-zespolu-eksperckiego,news, 24,209.php (dostęp: 9.03.2016). 
pkt 2 i ust. 3 u.p.s. Złożona podstawa prawna niestety powoduje, że urzędnicza praktyka stosowania prawa nie jest w tym zakresie ani poprawna, ani jednolita.

Zważywszy jednak na przyjęcie i uznanie przeważającego poglądu osadzonego w publicznoprawnej konstrukcji umowy i obowiązku wynikającym z ustawy, należy mieć nadzieję, że przewaga ta oraz argumentacja sądów będzie stanowić silne źródło ujednolicenia praktyki orzeczniczej i tym sposobem będzie stanowić dla obywatela i aparatu administracyjnego podstawę do budowy sprawnego i skutecznego państwa w obszarze pomocy społecznej.

\title{
Agreement on the charges for staying at a nursing home in the case law of administrative courts
}

\author{
Summary
}

This paper is devoted to the issue of concluding an agreement on the charges for staying at a nursing home in the case law of administrative courts. The debated issue is based on a very extensive case law and against this background the most important problems are discussed. The first problem concerns the sources and forms of participation in the cost of maintaining a person in a social welfare home. In the case law of administrative courts a prevailing view is that law is the source. Other opinion says that the source is an administrative decision. The second opinion cannot be accepted. The views in the case law of the courts tend to conclude that the source of the duty is the law and the agreement individualizes this obligation. Another issue concerns the refusal to conclude an agreement on participation in the cost of maintaining a person in a social assistance home. In this situation, in the case law a prevailing view is that an agreement may be replaced with a central administrative decision.

Keywords: administrative agreement, administrative decision, law, social assistance, nursing home, case law of administrative courts.

\section{Bibliografia}

Cieślik Z., Umowa administracyjna, Kraków 2008.

Instytucje współczesnego prawa administracyjnego. Księga Jubileuszowa Profesora zw. dra hab. Józefa Filipka, red. I. Skrzydło-Niżnik et al., Kraków 2001.

Kania M., Partnerstwo publiczno-prywatne. Teoria i praktyka, Warszawa 2013.

Kłos A., Kontrakt socjalny w teorii i w praktyce, Warszawa 2011.

Longchamps de Bérier F., W sprawie pojęcia administracji państwowej i pojęcia prawa administracyjnego, Wrocław 1957, (,Zeszyty Naukowe Uniwersytetu Wrocławskiego” nr 10).

Ochendowski E., Prawo administracyjne. Część ogólna, Torun 2013.

Prandota-Prandecka E., Kontrakt socjalny jako narzędzie rozwiazywania trudnej sytuacji życiowej beneficjenta pomocy społecznej - zagadnienia wybrane, [w:] Umowy w administracji publicznej, red. J. Boć, L. Dziewięcka-Bokun, Wrocław 2008.

Prawo administracyjne, red. J. Boć, Wrocław 2002.

Przybysz P., Umowa jako forma działań administracji w świetle pogladów Profesora Jerzego Starościaka, [w:] Umowy w administracji publicznej, red J. Boć, L. Dziewięcka-Bokun, Wrocław 2008 .

Prawo 320, 2016

(C) for this edition by CNS 
System prawa administracyjnego, red. T. Rabska, J. Łętowski, t. 3, Wrocław 1978.

Richter I., Schuppert G.F., Casebook. Verwaltungsrecht, München 1995.

Rypina M., Wierzbowski M., Umowa z organem w postępowaniu administracyjnym, „Państwo i Prawo" 2010, z. 4.

Sierpowska I., Prawo pomocy społecznej, Kraków 2006.

Sierpowska I., Ustawa o pomocy społecznej. Komentarz, Warszawa 2009.

Stec P., Umowy w administracji. Studium cywilnoprawne, Warszawa 2013.

Umowy w administracji publicznej, red. J. Boć, L. Dziewięcka-Bokun,Wrocław 2008.

Wyporska-Frankiewicz J., Publicznoprawne formy działań administracji o charakterze dwustronnym, Warszawa 2010.

Wyporska-Frankiewicz J., Cybulska R., Kontrakt socjalny jako doskonałe narzędzie stużace wspótdziałaniu w wykonywaniu zadań z zakresu pomocy społecznej ciążacych na administracji publicznej, [w:] Formy współdziałania jednostek samorządu terytorialnego, red. B. Dolnicki, Warszawa 2013.

Zacharko L., Cybulska R., Prandota-Prandecka E., Kontrakt socjalny. Pracownik socjalny, Wrocław 2011.

\section{Wykaz aktów prawnych}

Ustawa z dnia 12 marca 2004 r. o pomocy społecznej (tekst jedn. Dz.U. z 2015 r. poz. 163). 